\title{
Plant regeneration from axillary bud derived callus in white yam (Dioscorea rotundata)
}

\author{
Rajesh Manoharan $^{1} \cdot$ Jaindra Nath Tripathi $^{1} \cdot$ Leena Tripathi $^{1}$
}

Received: 18 November 2015/ Accepted: 6 June 2016/Published online: 14 June 2016

(C) The Author(s) 2016. This article is published with open access at Springerlink.com

\begin{abstract}
Dioscorea rotundata, commonly known as white yam, is an important staple food crop widely cultivated in West Africa and provides food security to millions of people. Genetic improvements of this crop using the advanced biotechnology tools have been hampered hitherto by the recalcitrant nature of regeneration through somatic embryogenesis. Therefore, we have developed an efficient and reproducible system for plant regeneration via somatic embryogenesis. Explants of different types (immature leaf, node, stem internode, root segment, petiole, and axillary bud) of D. rotundata accession TDr 2436 were tested for their embryogenic potentials on Murashige and Skoog (MS) medium supplemented with various auxins (2,4-D, NAA, and picloram). Among all explants tested, axillary bud explants cultured on MS medium supplemented with picloram $(0.5-12 \mathrm{mg} / \mathrm{l})$ favored the production of calli. Maximum proliferation of calli (526 mg fresh weight/explant) was achieved on MS medium supplemented with picloram $(0.5 \mathrm{mg} / \mathrm{l})$, casein hydrolysate $(600 \mathrm{mg} / \mathrm{l})$, and proline $(1 \mathrm{~g} / \mathrm{l})$. Histology analysis confirmed that the embryogenic calli produced on this medium were mixed with non-embryogenic calli. Transfer of calli on MS basal medium supplemented with activated charcoal (1\%) changed the color of calli to purple and promoted the production of somatic embryos ( 87 embryos/callus) as well as adventitious shoot buds. Furthermore, upon transfer to MS medium supplemented with BAP $(0.4 \mathrm{mg} / \mathrm{l})$, the embryos continued their differentiation and maturation and germinated into complete plantlets. The adventitious shoot
\end{abstract}

Leena Tripathi

L.Tripathi@ cgiar.org

1 International Institute of Tropical Agriculture, PO 30709-00100, Nairobi, Kenya buds produced multiple shoots on MS medium supplemented with BAP $(0.4 \mathrm{mg} / \mathrm{l})$. Well-developed germinated plantlets were acclimatized in the screen house with $90 \%$ survivability. Histology studies confirmed that the regeneration of $D$. rotundata reported here followed dual regeneration pathways. The embryogenic calli regenerated through development of somatic embryos and germinated into complete plantlets, however non-embryogenic calli regenerated through organogenesis and developed multiple shoots. The developed protocol has potential for somatic hybridization, mass clonal propagation, and genetic transformation applications.

Keywords Dioscorea rotundata $\cdot$ Somatic embryogenesis · Axillary bud · Picloram . Activated charcoal

\section{Introduction}

Yam (Dioscorea spp.) is an important staple food for millions of people in Africa, South America, Asia, and the Pacific tropical countries (FAO 2013). The crop has great economic and social significance in sub-Saharan Africa (Ile et al. 2006) where more than $95 \%$ of the world's yam is produced (FAO 2013). Of the 600 known Dioscorea species only 10 of the 90 edible species are consistently cultivated for food consumption (Nyaboga et al. 2014) and the Dioscorea rotundata species complex is among the most cultivated, especially in West Africa (FAO 2013). Besides its importance as a staple food, yam is also a source of income for people, particularly in the coastal region of West Africa (Asiedu and Sartie 2010). A number of Dioscorea species are also the source of phyto-compounds which are used in the production of corticosteroids and have potential uses as 
excipients in the pharmaceutical industry (Poornima and Ravishankar 2007; Zuluaga et al. 2007; Okunlola and Odeku 2011). Yam production has been constrained owing to several abiotic and biotic factors that include diseases and pests, inadequate planting material, low yield potential, and decreasing soil fertility (Amusa et al. 2003; Adegbite et al. 2006). Despite the vitality of yam, its genetic improvement through conventional breeding has been hindered by the prolonged breeding cycle, dioecious and erratic flowering nature, poor seed setting, polyploidy, vegetative propagation through seed tubers and vine cuttings, and heterozygous genetic background (Mignouna et al. 2008). So far, the application of genetic engineering to develop improved varieties has been limited by the absence of efficient protocols for regeneration and genetic transformation. The development of stable transgenic plants requires an efficient regeneration system amenable to Agrobacterium-mediated genetic transformation and the stability of transgenes under field conditions.

Regeneration systems through direct shoot organogenesis have been reported for D. rotundata, D. cayenensis, and D. alata (Adeniyi et al. 2008; Anike et al. 2012). Recently the production of transgenic plants of D. rotundata has been reported using nodal segments (Nyaboga et al. 2014). Although micropropagation of D. rotundata has been described (Adeniyi et al. 2008; Anike et al. 2012), there is no report on regeneration through somatic embryogenesis that has many advantages particularly for genetic transformation as embryos are unicellular in origin and avoid chances of chimerism (Mariashibu et al. 2013). Induction of somatic embryos using zygotic embryos as explants was first reported in D. rotundata by Osifo (1988) but regeneration of complete plantlets through somatic embryos was not achieved. Recently, Suarez Padron et al. (2011) reported somatic embryogenesis of D. rotundata using petiole explants; however, the report lacks information on the efficiency of induction of embryogenic calli and details about the different stages of embryo development. In fact, progress on somatic embryogenesis especially for food yam species, which include $D$. rotundata, D. bulbifera, D. dumetorum, D. esculenta, D. hispidia, D. japonicum, and D. trifida, is restricted by recalcitrance and genotype dependence. There are only a very few reports on the somatic embryogenesis of other species of food yam, namely $D$. composita and $D$. cayenensis (Viana and Mantell 1989); D. opposita (Nagasawa and Finer 1989), and D. alata (Twyford and Mantell 1996; Belarmino and Gonzales 2008) that reported a low efficiency of somatic embryo production and germination potential. The efficiency of somatic embryogenesis was not high enough for genetic transformation as the regeneration efficiency is normally reduced considerably after Agrobacterium infection. In addition, the reported somatic embryogenesis protocols for these species are not applicable to D. rotundata due to the genotypic effect; therefore protocols for calli induction, somatic embryos development and regeneration need to be optimized for each yam species.

Dioscorea rotundata, commonly known as white yam, is native to Africa and is among the most important cultivated species. It is also one of the most productive and has a high export potential wherever it is cultivated (Klu et al. 2005). However, an efficient regeneration system through somatic embryogenesis is not available. Therefore, there is an urgent need to develop a protocol for regeneration through somatic embryogenesis, which can be used for somatic hybridization, seed production, and genetic transformation. Hence, the present study was designed to develop efficient plant regeneration system through somatic embryogenesis in $D$. rotundata.

\section{Materials and methods}

\section{Plant material}

In vitro plantlets of $D$. rotundata accession number TDr 2436 were obtained from International Institute of Tropical Agriculture (IITA), Ibadan, Nigeria. The accession was maintained in vitro and multiplied through nodal cuttings on yam basic medium (YBM) containing Murashige and Skoog medium (MS) salts and vitamins, $0.05 \mathrm{mg} / \mathrm{l}$ 6-Benzylaminopurine (BAP), $0.02 \mathrm{mg} / \mathrm{l}$ Naphthaleneacetic acid (NAA), $25 \mathrm{mg} / 1$ Ascorbic acid, $30 \mathrm{~g} / 1$ sucrose, and $2.4 \mathrm{~g} / 1$ gelrite, as described by Nyaboga et al. (2014) (Fig. 1a). Six types of explant (immature leaf, node, stem internode, root, petiole, and axillary bud) were excised and tested for callus induction. For the axillary bud explants, nodal stem segments excised from 4-8 weeks old plantlets were placed on MS medium supplemented with BAP ( $1 \mathrm{mg} / \mathrm{l}$ ) for 3 days to induce axillary buds (Fig. 1b). After 3 days, axillary buds were isolated with a sterile needle under the microscope and used as explants for callus induction (Fig. 1c).

\section{Effect of auxins on different explants for callus induction}

The six different explants (immature leaf, node, stem internode, root segment, petiole and axillary bud) were cultured on MS medium supplemented with various auxins (2,4-D, NAA, picloram; Table 1) at different concentrations ranging from 0.5 to $9.0 \mathrm{mg} / \mathrm{l}$ to determine their effect on the induction of callus. Ten explants were cultured on each $90 \mathrm{~mm}$ Petri dish and a total of 100 explants were tested for each treatment; the experiment was repeated twice. All the cultures were incubated in complete darkness at $25 \pm 2{ }^{\circ} \mathrm{C}$. The explants producing direct somatic 

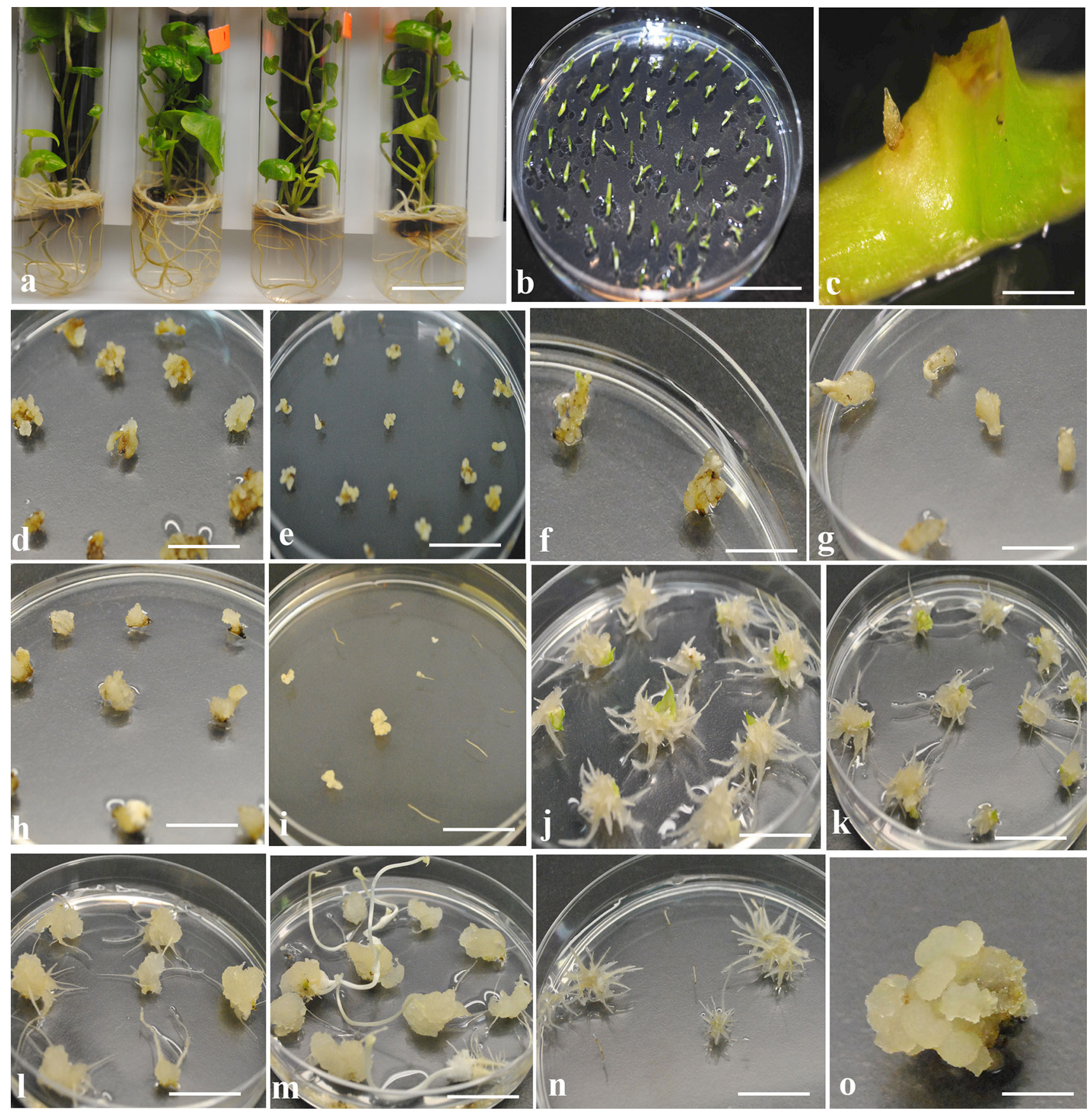

Fig. 1 Effect of auxins on explants of different types for embryogenic callus induction. a In vitro grown plants of D. rotundata (bar $0.2 \mathrm{~cm}$ ); $\mathbf{b}$ induction of axillary buds from nodal stem segments on MS medium supplemented with BAP (1 mg/l; bar $0.5 \mathrm{~cm})$; c microscopic image of 3 day grown axillary bud (bar $1 \mathrm{~mm}$ ); $\mathbf{d}$, e DSLS and callus from immature leaf in 2,4-D $(0.5 \mathrm{mg} / \mathrm{l})$ after 8 weeks of culture (bar $1 \mathrm{~cm})$; f DSLS from petiole explants in 2,4-D $(0.5 \mathrm{mg} / \mathrm{l})$ after 8 weeks of culture (bar $1 \mathrm{~cm})$; $\mathrm{g}$ axillary bud explants in 2,4-D $(0.5 \mathrm{mg} / \mathrm{l})$ after 8 weeks of culture (bar $1 \mathrm{~cm})$; h nodal stem explants in 2,4-D $(0.5 \mathrm{mg} / \mathrm{l})$ after 8 weeks of culture (bar $1 \mathrm{~cm})$; $\mathbf{i}$ root

embryo like structure (DSLS) and the number of DSLS/explant were recorded after 4 weeks of culture. The percentage of DSLS was calculated as the number of

explants in 2,4-D $(0.5 \mathrm{mg} / \mathrm{l})$ after 8 weeks of culture $($ bar $1 \mathrm{~cm})$; j immature leaf in NAA $(0.5 \mathrm{mg} / \mathrm{l})$ after 8 weeks of culture (bar $1 \mathrm{~cm})$; $\mathbf{k}$ petiole explants in NAA $(0.5 \mathrm{mg} / \mathrm{l})$ after 8 weeks of culture (bar $1 \mathrm{~cm})$; $\mathbf{l}$ axillary bud explants in NAA $(0.5 \mathrm{mg} / \mathrm{l})$ after 8 weeks of culture (bar $1 \mathrm{~cm})$; m nodal stem explants in NAA $(0.5 \mathrm{mg} / \mathrm{l})$ producing shoots and roots after 8 weeks of culture $($ bar $1 \mathrm{~cm}) ; \mathbf{n}$ root explants producing hairy roots at NAA $(0.5 \mathrm{mg} / \mathrm{l})$ after 8 weeks of culture (bar $1 \mathrm{~cm})$. o axillary bud explants producing yellowish-white callus in picloram $(9 \mathrm{mg} / \mathrm{l})$ after 8 weeks of culture (bar $1 \mathrm{~mm}$ ). (Color figure online)

explants showing DSLS induction/total number of explants cultured $100 \times$. Callus induction and type of callus were also recorded after 8 weeks of culture. 


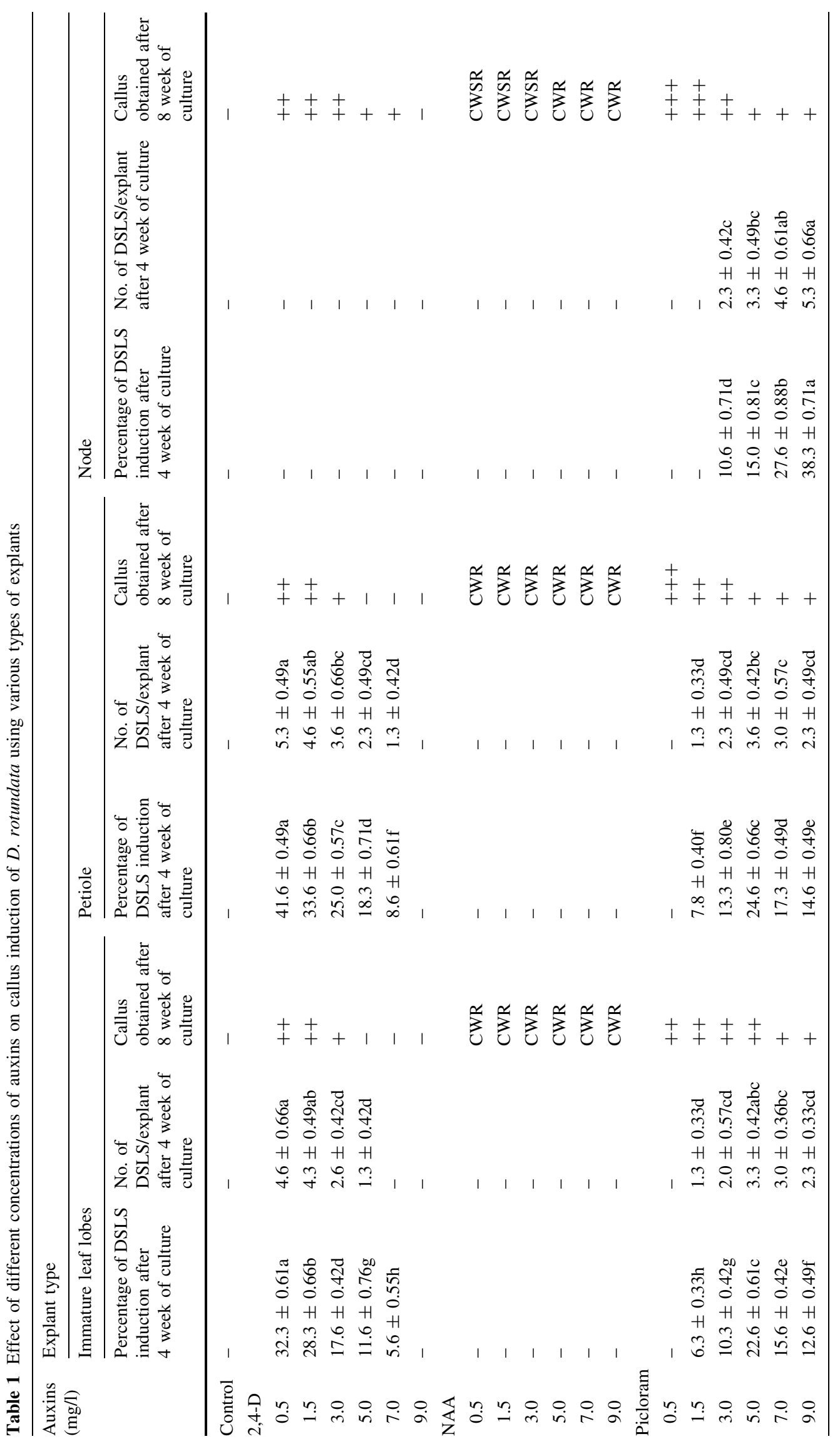




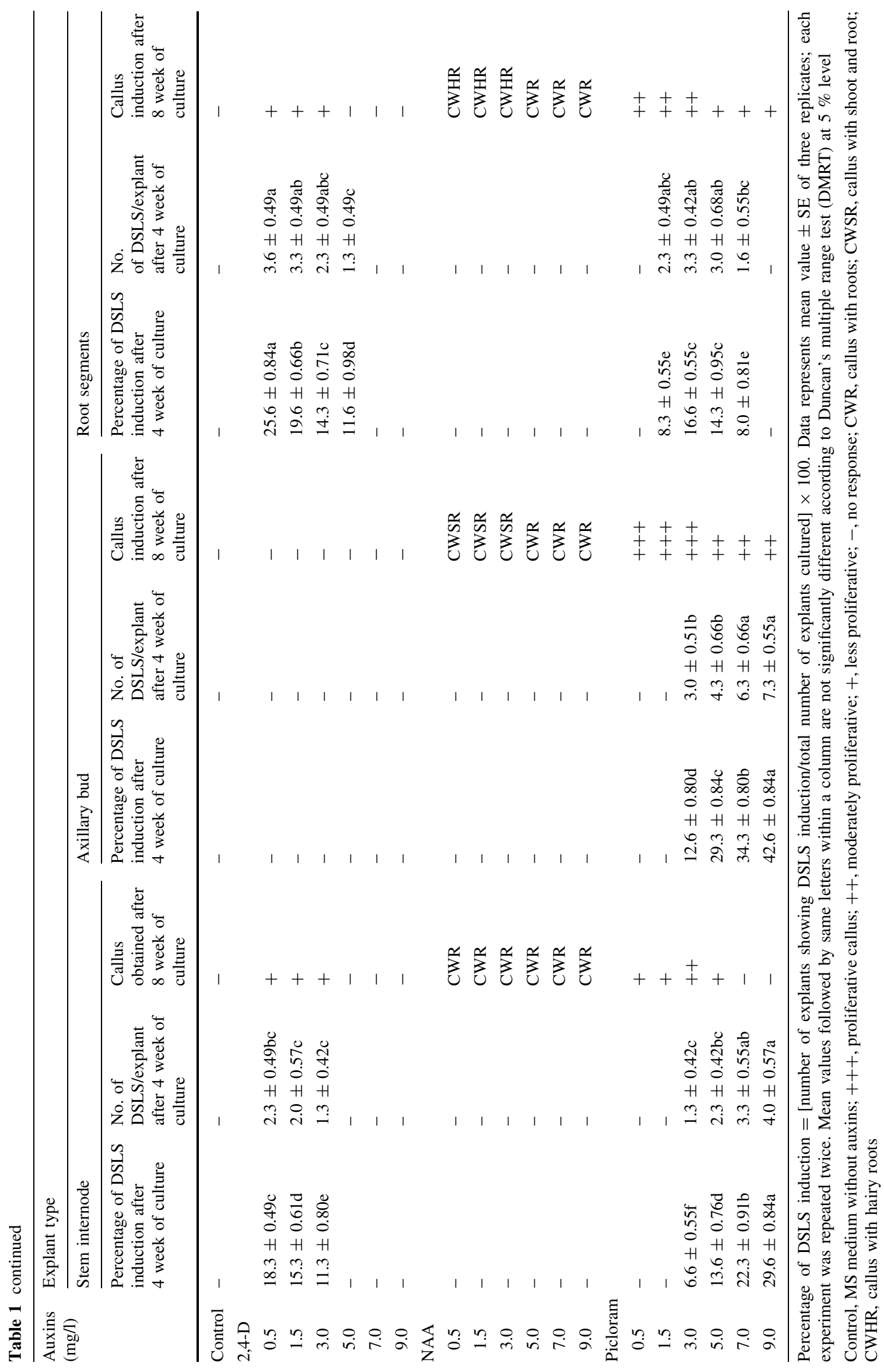




\section{Effect of picloram concentrations supplemented with copper sulfate on callus induction}

Based on the response of the different explants cultured on MS medium supplemented with different auxins, picloram and axillary bud explants were selected for further experiments. Axillary bud explants were cultured on MS medium supplemented with $0.318 \mathrm{mg} / \mathrm{l}$ copper sulfate, $2 \%$ sucrose, and different concentrations of picloram (ranging from 0.5 to $16 \mathrm{mg} / \mathrm{l}$; Table 2) to test the effect on induction of DSLS and callus production. Ten explants were cultured on each $90 \mathrm{~mm}$ Petri dish and a total of 100 explants were tested for each treatment; the experiments were repeated twice. All the cultures were incubated in complete darkness at $25 \pm 2{ }^{\circ} \mathrm{C}$. The percentage of explants showing induction of DSLS and the number of DSLS/explant were recorded after 4 weeks of culture. The fresh weight of calli was recorded after 8 weeks of culture.

\section{Effect of organic nitrogenous additives on callus induction}

Based on the response of axillary buds cultured on different concentrations of picloram, four different concentrations $(0.5,1.5,7$, and $12 \mathrm{mg} / \mathrm{l})$ of picloram were selected to test the effect of organic nitrogenous additives on induction of direct somatic embryos (DSE) and callus. Axillary bud explants were tested on MS medium supplemented with different concentrations of picloram $(0.5,1.5,7$, and $12 \mathrm{mg} /$ 1) in combination with casein hydrolysate $(600 \mathrm{mg} / \mathrm{l})$ and proline $(1 \mathrm{~g} / \mathrm{l})$. A total of 100 explants were used for each concentration and the experiments were repeated twice. The cultures were incubated in the dark at $25 \pm 2{ }^{\circ} \mathrm{C}$.

\section{Effect of activated charcoal on indirect somatic embryo induction}

Eight weeks old callus obtained on MS medium supplemented with different concentrations $(0.5,1.5,7$, and $12 \mathrm{mg} / \mathrm{l})$ of picloram in combination with casein hydrolysate $(600 \mathrm{mg} / \mathrm{l})$ and proline $(1 \mathrm{~g} / \mathrm{l})$ were aseptically transferred on MS basal medium augmented with different concentrations $(0,0.2$ and $1 \%)$ of activated charcoal for the induction of indirect somatic embryos. The cultures were incubated for 6 weeks at $25 \pm 2{ }^{\circ} \mathrm{C}$ with $16 \mathrm{~h}$ photoperiod with a photon flux density (PFD) of $50 \mu \mathrm{mol} \mathrm{m} \mathrm{m}^{-2} \mathrm{~s}^{-1}$ provided by a cool white fluorescent lamp. The response to indirect somatic embryo induction and the number of indirect somatic embryos/callus were recorded after 6 weeks of culture.

\section{Plant regeneration}

The calli were transferred to MS basal medium or MS medium supplemented with BAP concentrations (0.4, $1 \mathrm{mg} / \mathrm{l})$ to induce germination of embryos. Well-developed germinated embryos were separated from the callus clumps and cultured individually for proper shoot and root development in YBM. The number of germinated plantlets/callus cluster was recorded.

The complete plantlets were removed from culture tubes, washed with sterile water to remove attached agar,

Table 2 Effect of different concentrations of picloram on callus induction from axillary bud explants of D. rotundata on MS medium supplemented with $0.318 \mathrm{mg} / \mathrm{l}$ copper sulphate and $2 \%$ sucrose

\begin{tabular}{|c|c|c|c|c|}
\hline $\begin{array}{l}\text { Picloram } \\
\text { concentrations } \\
(\mathrm{mg} / \mathrm{l})\end{array}$ & $\begin{array}{l}\text { Percentage of DSLS } \\
\text { after } 4 \text { weeks of } \\
\text { culture }\end{array}$ & $\begin{array}{l}\text { No. of DSLS after } \\
4 \text { week of culture }\end{array}$ & $\begin{array}{l}\text { Percentage of callus } \\
\text { induction after } 8 \text { weeks } \\
\text { of culture }\end{array}$ & $\begin{array}{l}\text { Fresh weight of } \\
\text { the callus (mg) }\end{array}$ \\
\hline Control & - & - & - & - \\
\hline 0.5 & $15.6 \pm 0.98 \mathrm{~h}$ & $2.3 \pm 0.49 \mathrm{~d}$ & $99 \pm 0.36 a$ & $222.3 \pm 0.55 a$ \\
\hline 1.5 & $17.6 \pm 0.76 \mathrm{~h}$ & $2.6 \pm 0.55 \mathrm{~d}$ & $98 \pm 0.57 a$ & $207.3 \pm 0.98 b$ \\
\hline 3.0 & $27.3 \pm 0.88 \mathrm{~g}$ & $4.0 \pm 0.57 d$ & $97 \pm 0.57 \mathrm{ab}$ & $185.3 \pm 0.66 c$ \\
\hline 5.0 & $36.6 \pm 0.88 f$ & $6.3 \pm 0.71 c$ & $95 \pm 0.96 b c$ & $179.3 \pm 0.98 \mathrm{~d}$ \\
\hline 7.0 & $48.6 \pm 0.88 \mathrm{e}$ & $8.6 \pm 0.95 b$ & $94 \pm 0.89 c$ & $171.3 \pm 0.88 \mathrm{e}$ \\
\hline 9.0 & $52.6 \pm 0.80 \mathrm{~d}$ & $11.0 \pm 0.93 a$ & $94 \pm 0.93 c$ & $167.6 \pm 0.88 f$ \\
\hline 12.0 & $64.6 \pm 0.80 \mathrm{a}$ & $12.3 \pm 0.66 \mathrm{a}$ & $94 \pm 0.57 \mathrm{c}$ & $161.3 \pm 0.66 \mathrm{~g}$ \\
\hline 14.0 & $60.3 \pm 0.98 b$ & $11.3 \pm 0.88 \mathrm{a}$ & $88 \pm 0.85 \mathrm{~d}$ & $153.6 \pm 0.91 \mathrm{~h}$ \\
\hline 16.0 & $57.3 \pm 0.95 c$ & $10.6 \pm 0.76 a b$ & $83 \pm 0.81 \mathrm{e}$ & $145.3 \pm 0.55 i$ \\
\hline
\end{tabular}

Percentage of DSLS induction $=$ [number of explants showing DSLS induction/total number of explants cultured] $\times 100$. Data represents mean value $\pm \mathrm{SE}$ of three replicates; each experiment was repeated twice. Mean values followed by same letters within a column are not significantly different according to Duncan's multiple range test (DMRT) at $5 \%$ level

Control, MS medium without Picloram 
transferred to peat pellets, and covered with polythene bags for 4 weeks to maintain humidity. The acclimatized plants were then transferred to pots containing soil and manure in the ratio of $1: 1$ and kept in the screen house for further growth.

\section{Histological analysis}

Histological analysis was performed following the method of Filonova et al. (2000) with slight modification. The plant tissues at different stages of somatic embryogenesis were fixed in the solution of formalin, acetic acid, and alcohol containing $5 \mathrm{ml}$ of $96 \%$ ethanol, $10 \mathrm{ml}$ of $37 \%$ formaldehyde, and $5 \mathrm{ml}$ of acetic acid, adjusted to $100 \mathrm{ml}$ of volume with distilled water, and stored at $10^{\circ} \mathrm{C}$ for $48 \mathrm{~h}$. After fixing, the samples were dehydrated by successive changes in ethanol at different concentrations $(30-100 \% \mathrm{v} / \mathrm{v})$. After dehydration, the samples were embedded in Technovit 7100 resin (Kulzer Germany). Serial sections $(5 \mu \mathrm{m})$ were cut in a rotary microtome (Leica RM 2155, USA), mounted on cytological glass slides, and stained with $0.05 \%$ toluidine blue for $4 \mathrm{~min}$.

\section{Photomicrography}

Different stages of somatic embryo differentiation were observed and photographed using Nikon Stereo microscope equipped with Nikon color digital camera system DS-Fi1U2 (100-240 V, Nikon, Japan) consisting of the NIS elements software package. The histological sections were observed and photographed using the light microscope (Coslab, India) equipped with a digital camera system consisting of optika vision lite 2.1 image analyzing software.

\section{Statistical analysis}

A completely randomized design was used for all treatments. All the experiments were repeated twice with three replicates for each treatment of 100 explants. Data were statistically analyzed using analysis of variance (ANOVA) and presented as the mean \pm standard error (SE). The means were separated using Duncan's multiple range tests and significance was determined at $5 \%$ level using SPSS version 11.5.

\section{Results and discussion}

Developing an efficient and reproducible regeneration system through somatic embryogenesis is a prerequisite for rapid mass clonal propagation, genetic transformation, and artificial seed production for economically important genotypes of yam. However, establishment of a plant regeneration system through somatic embryogenesis for most of the species has been very challenging due to the poor response in tissue culture manipulations (Twyford and Mantell 1996). Although some progress has been made in the in vitro propagation of $D$. rotundata using meristem culture (Adeniyi et al. 2008; Anike et al. 2012), no efficient protocol has been reported yet for regeneration through somatic embryogenesis. Therefore, this study was conducted to establish an efficient and robust plant regeneration system through somatic embryogenesis of $D$. rotundata. Several critical factors were optimized, such as the effect of different explants, auxins, organic nitrogenous additives, and activated charcoal.

\section{Effect of auxins on different explants for callus induction}

Regeneration of edible yam species through somatic embryogenesis is so far limited to only few reports (Osifo 1988; Nagasawa and Finer 1989; Viana and Mantell 1989; Twyford and Mantell 1996; Belarmino and Gonzales 2008). Selection of appropriate explants is a critical step for callus induction and somatic embryogenesis for any plant species particularly monocots where cells differentiate rapidly, followed by the loss of mitotic and morphogenetic ability (Krishnaraj and Vasil 1995). In yam, shoot meristem-tips, axillary nodes, and petioles have been used for organogenesis and regeneration (Borges et al. 2004; Ovono et al. 2007; Anike et al. 2012). Explants like zygotic embryos in D. rotundata, D. composita, and D. cayenensis (Osifo 1988; Viana and Mantell 1989); stem segments in D. opposita (Nagasawa and Finer 1989); root segments and nodal stem segments in D. alata (Twyford and Mantell 1996; Belarmino and Gonzales 2008) have been demonstrated to induce somatic embryos from edible species of yam. Based on these earlier reports, different explants were tested in this study for their potential for somatic embryogenesis by the application of suitable auxins.

Explants of different types from $D$. rotundata cultured on MS medium containing various concentrations of auxins showed differential responses to callus induction, depending on type and concentration of auxins (Table 1). MS medium devoid of auxins did not show callus induction (Table 1). All the explants tested showed a better response for callus induction on the medium supplemented with different concentrations of 2,4-D, and picloram compared with NAA (Table 1). Different types of calli were produced from different types of explants and auxins tested (Fig. 1). DSLS were observed during the first 4 weeks of culture and later formation of calli was observed after 8 weeks of culture on the same medium. The immature leaf and petiole explants produced DSLS with efficiencies of 
32.3 and $41.6 \%$, after 4 weeks of culture on MS medium containing $0.5 \mathrm{mg} / 1$ 2,4-D (Table 1; Fig. 1d-f). However, no callus was obtained from axillary bud explants on all the 2,4-D concentrations tested (Fig. 1g). Nodal explants produced calli on MS medium containing $0.5 \mathrm{mg} / 1$ 2,4-D (Table 1; Fig. 1h). Stem internode segments and root explants resulted in a lower frequency (18.3 and $25.6 \%$ ) of DSLS and calli on MS medium containing $0.5 \mathrm{mg} / 1$ 2,4-D (Table 1; Fig. 1i). Concentrations of 2,4-D more than $0.5 \mathrm{mg} / \mathrm{l}$ resulted in decreased efficiency of the calli induction from all the explants tested (Table 1).

Auxins are considered a major factor evoking embryogenic competence in somatic tissues to induce somatic embryogenesis (Feher et al. 2003; Gaj 2004). However, explants of different types respond differently to various auxins. In the present study, explants such as axillary buds and nodes cultured on picloram showed a better response for callus induction than with 2,4-D. Among the explants tested, axillary buds and nodes produced the maximum response for the induction of calli compared with petiole, immature leaf, stem internode, and root explants (Table 1). A similar phenomenon has been reported for $D$. alata by Belarmino and Gonzales (2008). However, Nagasawa and Finer (1989) reported induction of embryogenic calli from internode stem segments on a medium containing 2,4-D. Osifo (1988) used zygotic embryos for the induction of embryogenic calli on a medium supplemented with NAA in $D$. rotundata. In this study, NAA at all concentrations produced watery calli with adventitious shoots and/or roots in all explants tested (Fig. $1 \mathrm{j}-\mathrm{m}$ ). However, the root segments produced no calli but formed hairy roots at lower concentrations $(0.5-3 \mathrm{mg} / \mathrm{l})$ of NAA (Fig. 1n). The differences reported in this study from the previous reports could be due to the different cultivars of yam. The above results show that various types of explants vary in their response to different auxins in the medium, suggesting that explant type is an important factor in evoking somatic embryogenesis, as reported by Lincy et al. (2009). In this study, the calli obtained from different explants were further tested for differentiation of somatic embryos on different media supplemented with different cytokinins. All the calli produced roots instead of germination of somatic embryos. Based on the results observed for callus induction (Fig. 1o), axillary bud explants and picloram were chosen for further experiments.

\section{Effect of different concentrations of picloram supplemented with copper sulfate on callus induction}

Several factors are critical for the induction of embryogenic calli including type and age of explants, culture medium, concentration and combination of plant growth regulators (Prakash and Gurumurthi 2010). In the present study, the size and age of the axillary bud explants were found to be critical for calli induction in D. rotundata. The axillary buds of $0.1 \mathrm{~mm}$ size (Fig. 1c) isolated from nodal explants cultured on MS medium supplemented with BAP (1 mg/l) for 3 days (Fig. 1b) produced calli whereas axillary buds isolated after 4-5 days post-culture resulted in unorganized compact structures and showed poor response for callus induction.

In this study, the effect of different concentrations of picloram in combination with copper sulfate was examined. Table 2 demonstrates the influence of different concentrations of picloram in MS medium supplemented with $0.318 \mathrm{mg} / \mathrm{l}$ copper sulfate for the induction of calli from axillary bud explants. Copper sulfate has been reported to induce embryogenic calli in several crops such as cassava and sorghum (Nirwan and Kothari 2003; Feitosa et al. 2007).

In the present study, axillary bud explants producing DSLS and calli were markedly influenced by the concentrations of picloram used (Table 2). The percentage of explants $(64.6 \%)$ producing DSLS and the number of DSLS/explant (12.3 DSLS/explant) were found to be maximum on MS medium supplemented with $12 \mathrm{mg} / \mathrm{l}$ picloram. However, maximum callus induction and proliferation was achieved at 0.5 and $1.5 \mathrm{mg} / \mathrm{l}$ picloram with fresh weight of 222 and $207 \mathrm{mg} /$ callus cluster, respectively (Table 2). The compact globular structures could be the result of high picloram concentrations whereas callus proliferation is maximum at the lower concentration due to the rapid division of cells. At lower concentrations (0.5 and $1.5 \mathrm{mg} / \mathrm{l})$ of picloram, the majority of calli were soft, compact, yellowish, and embryogenic in nature, in addition to some yellowish or white cotton wool types of non-embryogenic calli (Fig. 2a, b). At concentrations of 3-16 mg/l of picloram, the calli were hard, compact, and yellowish with globular structures (Fig. 2c, d). White compact structures were also observed at both higher and lower concentrations of picloram. Prolonged culture of calli on the same medium with higher concentrations $(12 \mathrm{mg} / \mathrm{l}$ or above) of picloram for 8 weeks resulted in browning of the calli and exudation of mucous secretions. In this study, it has been clearly indicated that picloram has the potential for the induction of calli. These results were similar to those of Belarmino and Gonzales (2008) who revealed that picloram is essential for callus induction and somatic embryogenesis in yam. Picloram has been successfully employed for the induction of friable embryogenic calli in root and tuber crops, especially cassava, sweet potato, and yam (Nyaboga et al. 2013; Triqui et al. 2008; Belarmino and Gonzales 2008). The copper sulfate used in the media combination with auxins creates oxidative stress conditions 

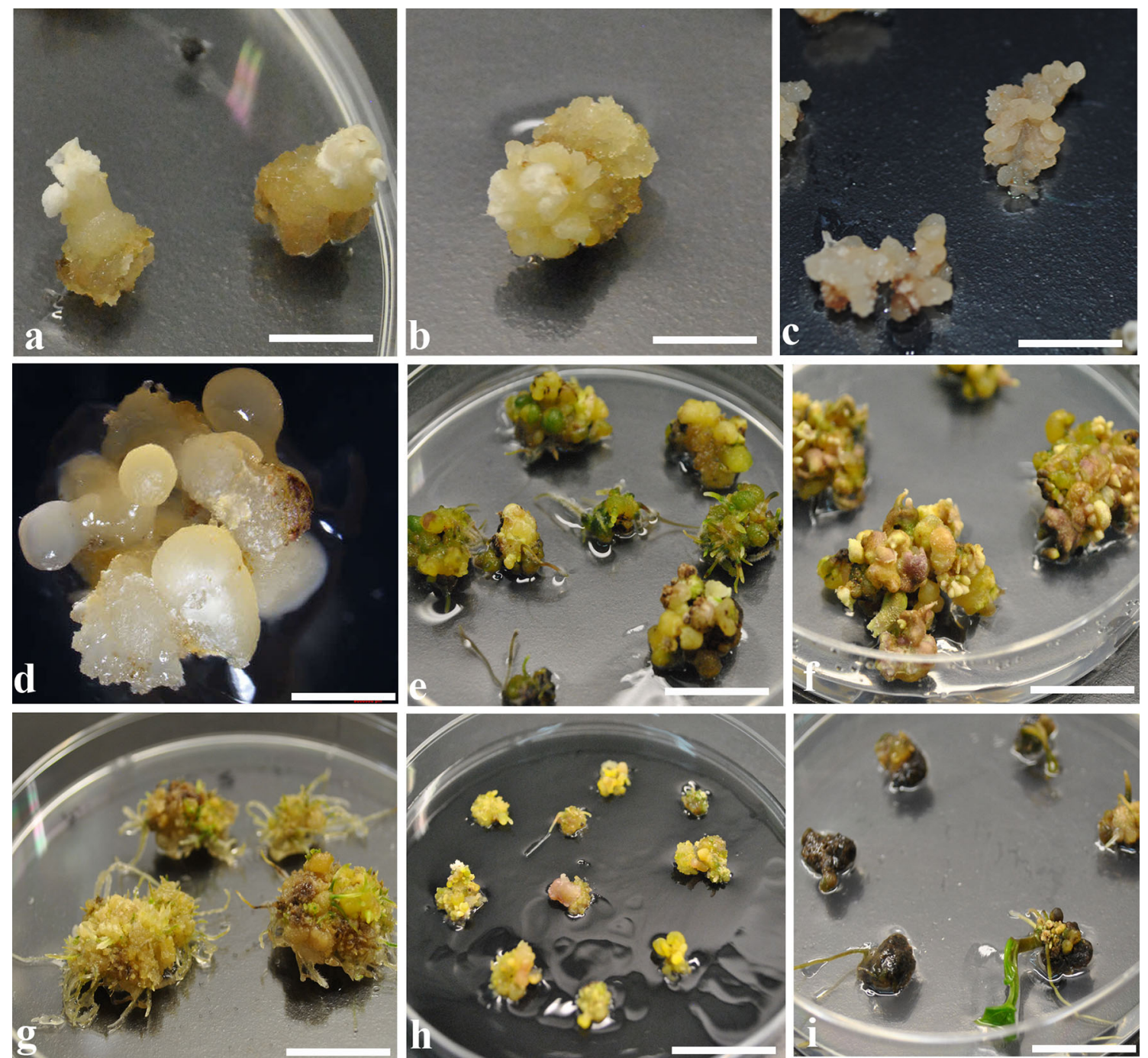

Fig. 2 Effect of different media containing various concentrations of picloram and supplemented with copper sulfate for callus induction from axillary bud explants. a, b Soft, compact yellowish calli along with white structures derived from picloram $(0.5 \mathrm{mg} / \mathrm{l})$ after 8 weeks of culture (bar 1 and $1 \mathrm{~mm}$, respectively); c hard compact callus derived from picloram $(12 \mathrm{mg} / \mathrm{l})$ after 8 weeks of culture $($ bar $1 \mathrm{~cm})$; d microscopic image of callus derived from picloram $(12 \mathrm{mg} / \mathrm{l}$; bar $1 \mathrm{~mm})$; e callus derived from picloram $(12 \mathrm{mg} / \mathrm{l})$ formed roots in MS

that promote both cell division and embryogenic cell formation, as reported by Pasternak et al. (2002).

The callus produced on picloram were transferred to MS basal medium and MS medium supplemented with different cytokinins for subsequent regeneration and embryo maturation but all the callus produced roots instead of germination into plantlets (Fig. 2e-g). Callus derived from medium containing high picloram concentration produced more roots in comparison to callus derived from low picloram concentrations. This result indicates that picloram might have inhibitory effect on differentiation and maturation of somatic embryos. basal medium and MS medium supplemented with BAP (1 mg/l; bar $1 \mathrm{~cm}) ; \mathbf{f}, \mathbf{g}$ formation of more roots in MS medium supplemented with $\mathrm{GA}_{3}(1 \mathrm{mg} / \mathrm{l}$; bar $1 \mathrm{~cm})$; $\mathbf{h}$ root formation was arrested in MS medium supplemented with activated charcoal (1\%) medium after 6 weeks of culture (bar $1 \mathrm{~cm}$ ); $\mathbf{i}$ germination of callus derived from picloram $(12 \mathrm{mg} / \mathrm{l})$ in MS medium supplemented with BAP $(0.4 \mathrm{mg} / \mathrm{l})$ prior to subculture in MS medium supplemented with activated charcoal medium for 6 weeks of culture (bar $1 \mathrm{~cm})$. (Color figure online)

Based on the high responsiveness of the explants for DSLS and calli induction, lower $(0.5$ and $1.5 \mathrm{mg} / \mathrm{l})$ and higher (7 and $12 \mathrm{mg} / \mathrm{l})$ concentrations of picloram were compared in further experiments in combination with organic additives.

\section{Effect of casein hydrolysate and proline in combination with picloram on callus induction}

Organic additives such as casein hydrolysate are complex nutrients containing a mixture of up to 18 amino acids and might contain some unknown growth promoting factor 

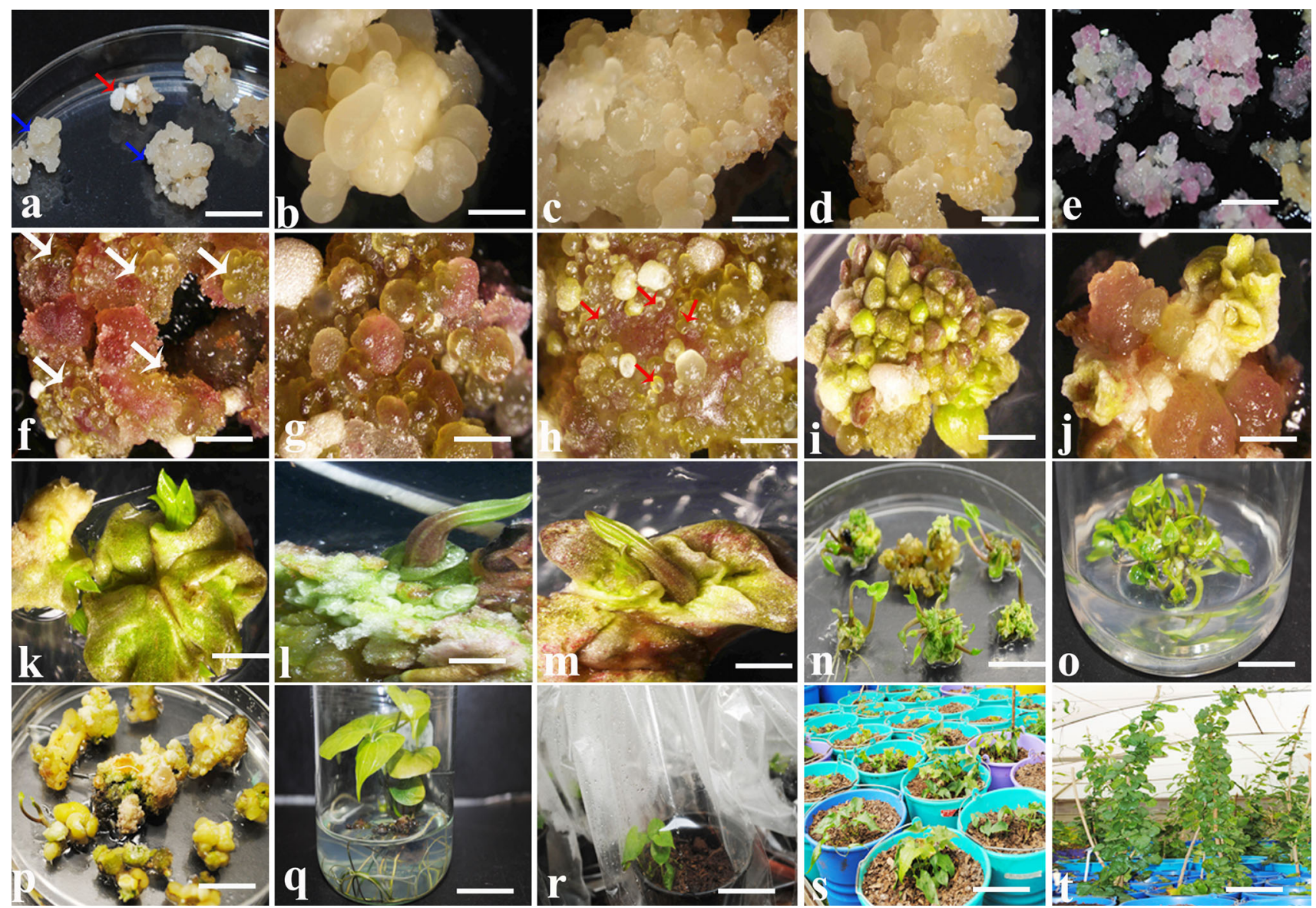

Fig. 3 Somatic embryogenesis and plant regeneration in D. rotundata TDr 2346. a callus derived from picloram $(0.5 \mathrm{mg} / \mathrm{l})$ supplemented with casein hydrolysate $(600 \mathrm{mg} / \mathrm{l})$ and proline $(1 \mathrm{~g} / \mathrm{l})$ after 8 weeks of culture. Blue arrow indicates the milky-white callus. Red arrow indicates white puffy structures (bar $1 \mathrm{~cm})$; b, c microscopic image of callus derived from picloram $(0.5 \mathrm{mg} / \mathrm{l})$ supplemented with casein hydrolysate $(600 \mathrm{mg} / \mathrm{l})$ and proline $(1 \mathrm{~g} / \mathrm{l}$; bar $1 \mathrm{~mm})$; d microscopic image of milky-white DSE derived from picloram $(0.5 \mathrm{mg} / \mathrm{l})$ supplemented with casein hydrolysate $(600 \mathrm{mg} / \mathrm{l})$ and proline $(1 \mathrm{~g} / \mathrm{l}$; bar $1 \mathrm{~mm})$; e callus derived from picloram $(0.5 \mathrm{mg} / \mathrm{l})$ supplemented with casein hydrolysate $(600 \mathrm{mg} / \mathrm{l})$ and proline $(1 \mathrm{~g} / \mathrm{l})$ turned purple in MS medium supplemented with activated charcoal $(1 \%)$ after 6 weeks of culture (bar $1 \mathrm{~mm}$ ); $\mathbf{f}$ induction of indirect embryos on the surface of the purple callus on MS medium supplemented with BAP $(0.4 \mathrm{mg} / \mathrm{l}$; bar $1 \mathrm{~mm})$; $\mathbf{g}$ close up view of

(Gray and Conger 1985; George et al. 2008). In the present investigation, a combination of casein hydrolysate and proline was added to MS medium containing picloram at various concentrations $(0.5,1.5,7$, and $12 \mathrm{mg} / \mathrm{l})$ to determine their effect on callus production. Translucent, smooth, milky-white calli were developed after 8 weeks of culture in all concentrations of picloram supplemented with casein hydrolysate and proline (Fig. 3a-d). The percentage of explants producing callus varied with different concentrations of picloram (Table 3). Maximum milky-white the somatic embryos (bar $1 \mathrm{~mm}$ ); h development of somatic embryos-arrow indicates opening of the somatic embryos at end of first subculture in MS medium supplemented with BAP $(0.4 \mathrm{mg} / \mathrm{l}$; bar $1 \mathrm{~mm}$ ); $\mathbf{i}$ continuation of the maturation of embryos by formation of cotyledonary collars (bar $1 \mathrm{~mm}$ ); $\mathbf{j}$ cup-shaped somatic embryos (bar $1 \mathrm{~mm}$ ); $\mathbf{k}$ germination of somatic embryos from the collars after second subculture in MS medium supplemented with BAP $(0.4 \mathrm{mg} / \mathrm{l}$; bar $1 \mathrm{~mm}$ ); l, $\mathbf{m}$ clear view of cotyledonary collars and hook type of germination (bar $1 \mathrm{~mm}$ ); $\mathbf{n}$, o germination of callus in MS medium supplemented with BAP $(0.4 \mathrm{mg} / \mathrm{l})$ after third subculture $($ bar $1 \mathrm{~cm})$; p germination from hard compact callus derived from picloram $(12 \mathrm{mg} / 1$; bar $1 \mathrm{~cm}) ; \mathbf{q}$ fully developed plantlet with shoot and root in YBM medium after fourth subculture (bar $1 \mathrm{~cm}$ ); $\mathbf{r}$ acclimatization of plants in polythene bags for 4 weeks (bar $1 \mathrm{~cm}$ ); $\mathbf{s}, \mathbf{t}$ hardened plants in screen house (bar $1 \mathrm{~cm})$. (Color figure online) direct somatic embryo (DSE) were obtained from picloram $(12 \mathrm{mg} / \mathrm{l})$ supplemented with casein hydrolysate and proline with 19.6 embryos/explant after 4 weeks of culture (Table 3). However, the proliferation of calli was low at this concentration, producing $348.3 \mathrm{mg}$ of fresh weight after 8 weeks of culture. The calli proliferation $(526.6 \mathrm{mg})$ was highest on MS medium supplemented with picloram $(0.5 \mathrm{mg} / \mathrm{l})$ supplemented with casein hydrolysate and proline after 8 weeks of culture. The histological analysis of callus produced on picloram $(0.5 \mathrm{mg} / \mathrm{l})$ supplemented with 
Table 3 Effect of different concentrations of picloram in combination with casein hydrolysate and proline for the induction of direct somatic embryo (DSE) and callus from axillary bud explants of $D$. rotundata

\begin{tabular}{|c|c|c|c|}
\hline $\begin{array}{l}\text { Picloram } \\
\text { concentrations } \\
(\mathrm{mg} / \mathrm{l})\end{array}$ & $\begin{array}{l}\text { Percentage of DSE } \\
\text { induction after } 4 \text { weeks } \\
\text { of culture }\end{array}$ & $\begin{array}{l}\text { No. of DSE/explant } \\
\text { after } 4 \text { weeks of culture }\end{array}$ & $\begin{array}{l}\text { Fresh weight of the callus } \\
(\mathrm{mg}) / \text { explant after } 8 \text { week } \\
\text { of culture }\end{array}$ \\
\hline 0.5 & $67.6 \pm 0.91 \mathrm{c}$ & $11.6 \pm 0.95 c$ & $526.6 \pm 0.66 \mathrm{a}$ \\
\hline 1.5 & $69.6 \pm 0.88 \mathrm{c}$ & $14.3 \pm 0.95 b$ & $488.3 \pm 0.66 b$ \\
\hline 7.0 & $86.3 \pm 0.66 b$ & $19.0 \pm 0.85 a$ & $402.3 \pm 0.76 c$ \\
\hline 12.0 & $89.6 \pm 0.88 a$ & $19.6 \pm 0.76 a$ & $348.3 \pm 0.84 d$ \\
\hline
\end{tabular}

Percentage of DSE induction $=$ [number of explants showing DSE induction/total number of explants cultured] $\times 100$. Data represents mean value $\pm \mathrm{SE}$ of three replicates; each experiment was repeated twice. Mean values followed by same letters within a column are not significantly different according to Duncan's multiple range test (DMRT) at $5 \%$ level

casein hydrolysate and proline confirmed production of DSE after 4 weeks of culture (Fig. 4b) and proliferation of both embryogenic and non-embryogenic type of calli after 8 weeks of culture (Fig. 4c).

In the present study, a significant interaction was observed between callus induction and picloram concentrations. The proliferation of calli gradually decreased with the increase in the picloram concentrations (Table 3). The translucent, smooth, milky-white calli were dominant in the medium supplemented with casein hydrolysate and proline compared with results from the medium without these additives. However, opaque compact white structures were also observed on picloram $(0.5 \mathrm{mg} / \mathrm{l})$ after 6 weeks of culture (Fig. 3a). The addition of casein hydrolysate alone to the MS medium containing picloram induced the formation of a layer of globular structures but there was no efficient callus proliferation (data not shown). However, the addition of proline alone to the MS medium containing picloram did not induce the formation translucent globular embryos (data not shown). It is the combination of casein hydrolysate and proline that resulted in the significant increase in number of DSE and proliferation of calli as indicated by fresh weight, in comparison to MS medium containing picloram and devoid of casein hydrolysate and proline (Tables 2,3). These results suggest that the combination of casein hydrolysate and proline is essential in induction and proliferation of callus for $D$. rotundata (Table 3). Osifo (1988) observed induction of somatic embryos in MS medium supplemented with NAA and casein hydrolysate $(1 \mathrm{~g} / \mathrm{l})$ using zygotic embryos as explants in $D$. rotundata under light conditions and obtained soft, creamy-white calli with an average of 4.5 embryos/explant. Takamori et al. (2015) made similar observations in Urochloa species using picloram and casein hydrolysate to obtain embryogenic calli. The addition of casein hydrolysate and proline to the medium increased embryogenic callus formation in Allium cepa, Triticum aestivum, and Oryza sativa (Khaleda and AlForkan 2006; Sarker et al. 2007; Ramakrishnan et al.
2013). The presence of amino acids in the culture medium is a source of $\mathrm{NH}_{4}^{+}$. Their supplement at optimal concentrations can increase the level of reduced nitrogen, which stimulates somatic embryo induction and development (Ramakrishnan et al. 2013).

\section{Effect of activated charcoal on indirect somatic embryo induction}

In this study, the calli derived from picloram in combination with casein hydrolysate and proline, sub-cultured on the basal medium or cytokinin (BAP, $\mathrm{GA}_{3}$ ) amended medium did not support embryo maturation and germination but produced adventitious roots instead of embryos germinating into plantlets (Fig. 2e-g). This could be because of the effect of exogenous or endogenous auxin imbalances in yam calli, which might have caused the formation of roots and failure to develop embryos and subsequent germination on MS basal medium and MS medium supplemented with BAP. Therefore, we evaluated the effect of different concentrations of activated charcoal $(0.2$ and $1 \%)$ on the induction of secondary somatic embryos, differentiation and maturation of somatic embryos from embryogenic calli derived from media with different concentrations $(0.5,1.5,7,12 \mathrm{mg} / \mathrm{l})$ of picloram (Table 3). The transfer of calli to MS medium containing activated charcoal (1\%) for 6 weeks induced the formation and development of somatic embryos. Depending upon the concentrations of activated charcoal and picloram, the calli produced anthocynins and induced the formation of indirect somatic embryos (Table 4; Fig. 3e-h). There was a significant interaction between different concentrations of activated charcoal and calli derived from different picloram concentrations on anthocynin and frequency of somatic embryos induction (Table 4; Fig. 3e-g). Calli derived from lower concentrations $(0.5$ and $1.5 \mathrm{mg} / \mathrm{l})$ of picloram showed more purple coloration in MS medium supplemented with $1 \%$ activated charcoal compared with 

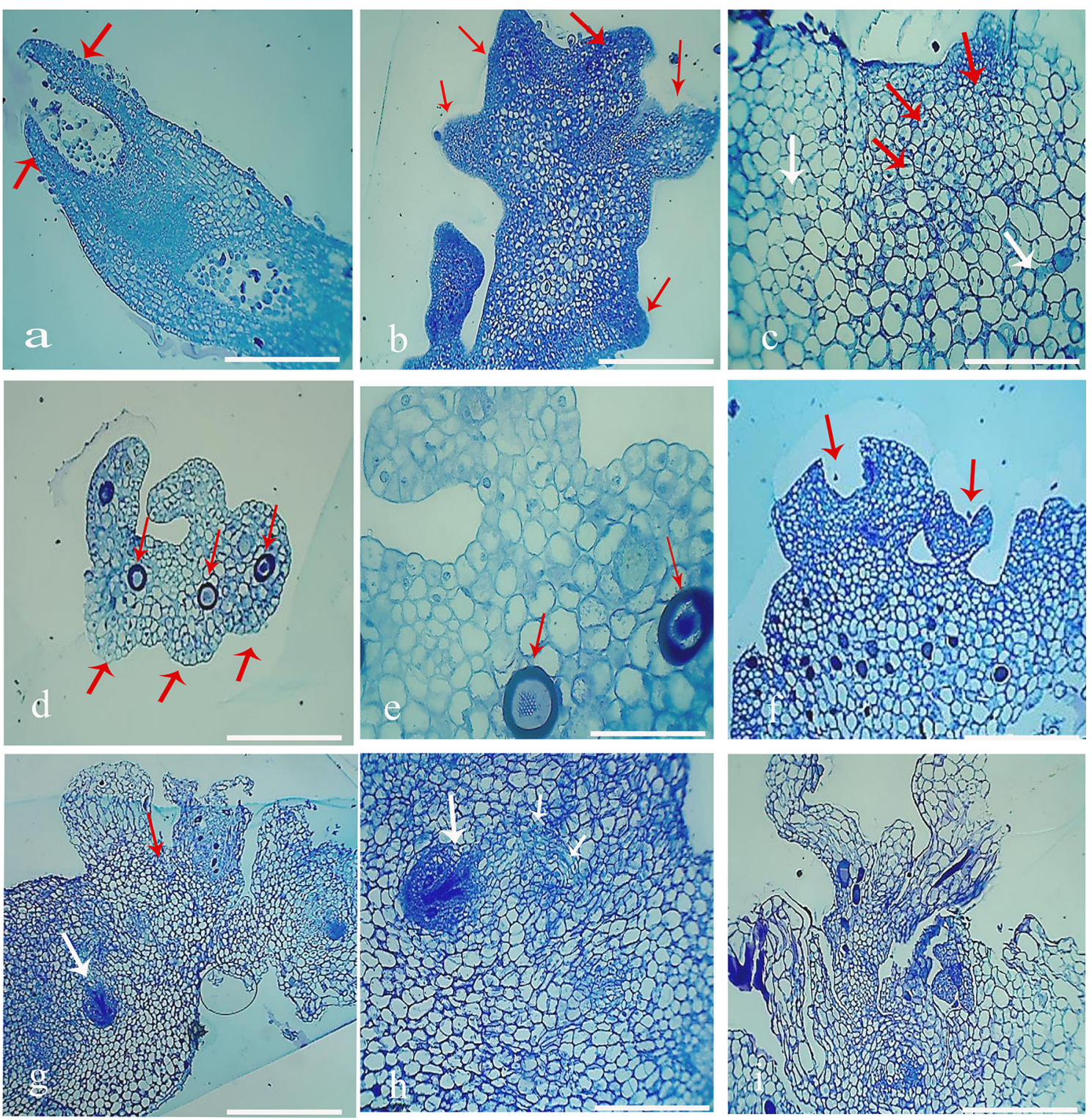

Fig. 4 Histology of somatic embryogenesis in D. rotundata. a LS (longitudinal) section view of 3 day old axillary bud with apical portion (arrows); b LS of axillary bud explant containing direct somatic embryo induction at the apical potion (arrows); c TS (transverse) section of the callus showing the group of embryogenic (red arrows) and non-embryogenic cells (white arrows); d TS of embryogenic callus showing induction of somatic embryos and starch grains (arrows); e higher magnification view of starch grains (arrows); $\mathbf{f}$ TS of callus showing adventitious bud induction (arrows); g mature somatic embryo showing shoot apical meristem (red arrow) and root apical meristem (white arrow); $\mathbf{h}$ higher magnification view of root apical meristem; i showing germination of plantlet. Scale bar $200 \mu \mathrm{m}(\mathbf{a}, \mathbf{b}, \mathbf{g}$ and $\mathbf{i}), 150 \mu \mathrm{m}(\mathbf{d}$ and $\mathbf{f}) 100 \mu \mathrm{m}(\mathbf{c}$ and $\mathbf{h}), 50 \mu \mathrm{m}(\mathbf{e})$. (Color figure online) calli derived from higher concentrations ( 7 and $12 \mathrm{mg} / \mathrm{l}$ ) of picloram. These purple calli from 0.5 and $1.5 \mathrm{mg} / \mathrm{l}$ concentrations of picloram led to the production of a high frequency of somatic embryos (70.6 and $63.3 \%$, respectively) on MS medium supplemented with $1 \%$ activated charcoal (Table 4; Fig. 3e-h). The numbers of somatic embryos/calli produced at 0.5 and $1.5 \mathrm{mg} / \mathrm{l}$ concentrations of picloram were 87.3 and 72.3 , respectively. The calli derived from 7 to $12 \mathrm{mg} / \mathrm{l}$ picloram concentrations produced a low frequency (38 and $24.6 \%$, respectively) of somatic embryos (Table 4; Fig. 3p). The low frequency of somatic embryos formed from calli derived from higher concentrations of picloram could be due to the compact calli, which contained few pro-embryos that failed to proliferate in picloram medium amended with casein hydrolysate and proline. MS medium supplemented with $1 \%$ activated charcoal was found to be optimal to induce purple coloration, which led to maximum somatic embryo production when compared with $0.2 \%$ activated charcoal (Table 4). The calli derived from all the concentrations of 
Table 4 Influence of activated charcoal on somatic embryo induction from callus derived from different picloram concentrations supplemented with casein hydrolysate and proline on MS medium after 6 weeks of culture

\begin{tabular}{|c|c|c|c|c|}
\hline $\begin{array}{l}\text { Picloram concentrations }(\mathrm{mg} / \mathrm{l}) \\
\text { from which callus was derived }\end{array}$ & $\begin{array}{l}\text { Activated } \\
\text { charcoal }(\%)\end{array}$ & $\begin{array}{l}\text { Purple coloration } \\
\text { of the callus }\end{array}$ & $\begin{array}{l}\text { Percentage of somatic } \\
\text { embryo induction }\end{array}$ & $\begin{array}{l}\text { No. of somatic } \\
\text { embryos per callus }\end{array}$ \\
\hline \multirow[t]{3}{*}{0.5} & 0 & + & - & Roots \\
\hline & 0.2 & ++ & $43.6 \pm 0.66 \mathrm{c}$ & $51.3 \pm 0.98 \mathrm{c}$ \\
\hline & 1 & +++ & $70.6 \pm 0.84 a$ & $87.3 \pm 0.76 a$ \\
\hline \multirow[t]{3}{*}{1.5} & 0 & - & - & Roots \\
\hline & 0.2 & ++ & $36.6 \pm 0.80 \mathrm{~d}$ & $38.6 \pm 0.88 \mathrm{~d}$ \\
\hline & 1 & +++ & $63.3 \pm 0.88 b$ & $72.3 \pm 0.55 b$ \\
\hline \multirow[t]{3}{*}{7.0} & 0 & - & - & Roots \\
\hline & 0.2 & + & $22.6 \pm 0.76 \mathrm{e}$ & $16.3 \pm 0.84 \mathrm{f}$ \\
\hline & 1 & ++ & $38.0 \pm 0.57 \mathrm{~d}$ & $34.6 \pm 0.55 \mathrm{e}$ \\
\hline \multirow[t]{3}{*}{12.0} & 0 & - & - & Roots \\
\hline & 0.2 & - & $13.6 \pm 0.91 \mathrm{f}$ & -* \\
\hline & 1 & + & $24.6 \pm 0.80 \mathrm{e}$ & $-*$ \\
\hline
\end{tabular}

Data represents mean value \pm SE of three replicates; each experiment was repeated twice. Mean values followed by same letters within a column are not significantly different according to Duncan's multiple range test (DMRT) at $5 \%$ level

* Callus has compact globular structures instead of shiny small globular embryos. Percentage of somatic embryo induction $=$ number of callus producing somatic embryo/total number of callus inoculated $\times 100$

picloram failed to proliferate when cultured on MS medium devoid of activated charcoal (Table 4). The callus upon transferring to MS medium supplemented with activated charcoal also produced adventitious shoot primordias, which was confirmed by histology (Fig. 4f). These results suggest that activated charcoal absorbs the picloram from the media efficiently and promotes the induction of somatic embryos as well as adventitious shoot buds. In most cases, auxin is required for the induction of somatic embryogenesis but is inhibitory for the maturation of somatic embryos. In general, differentiation of somatic embryos from calli occurs in the complete absence of auxins (Zimmerman 1993). Results of the present study show that removal of picloram and inclusion of activated charcoal in MS medium are crucial for indirect somatic embryo induction. This confirms the results of Jimenez (2001) who postulated that the removal of auxins resulted in the inactivation of a number of genes for the activation of the embryogenic program. Hence, the calli in the auxin enriched medium could not be able to synthesize all the gene products required to complete the globular stage of embryogenesis. It is suggested that calli need a certain amount of picloram to form somatic embryos and activated charcoal is important in absorbing the excess. Activated charcoal has also been reported to help in somatic embryo induction, maturation, or germination by absorbing toxic metabolites in several crop species (Thomas 2008). In Ocotea catharinensis, a forest tree species, somatic embryo induction occurred only on MS basal medium supplemented with $0.03 \mathrm{~g} / \mathrm{l}$ activated charcoal in the dark (Moura-Costa et al. 1993).

From the present study, it has been confirmed that picloram is essential for somatic embryogenesis in $D$. rotundata, although withdrawal of picloram and inclusion of activated charcoal are required for the proliferation and maturation of somatic embryos from calli. The inclusion of $1 \%$ activated charcoal for the picloram derived calli may have created a stress response which synthesized anthocyanins in the calli and turned them purple, leading to the formation of somatic embryos (Malabadi and van Staden 2006). López-Pérez et al. (2005) reported that activated charcoal enhanced somatic embryogenesis, shoot formation, and plant recovery, and helped in the prevention of abnormal somatic embryos in grapevine cultivars.

It has been reported from previous studies in other crops that activated charcoal reduces salt and growth hormone concentrations of the medium and substantially lowers the levels of phenylacetic and $p$-hydroxybenzoic acids which inhibit somatic embryogenesis (Bhansali and Singh 2000). It absorbs 5-hydroxymethyl furfural, an inhibitor formed by sucrose degradation during autoclaving, as well as the amount of auxins and cytokinins (Weatherhead et al. 1978). Activated charcoal also absorbs certain iron chelates preventing the transition from globular and heart-shaped embryos (Bhansali and Singh 2000). Therefore, in $D$. rotundata, the use of activated charcoal might have absorbed and removed various types of inhibitors that would have prevented somatic embryo induction and development. 
Table 5 Effect of different concentrations of BAP on germination of somatic embryos

\begin{tabular}{lll}
\hline $\begin{array}{l}\text { Picloram concentrations } \\
\text { (mg/l) from which callus } \\
\text { was derived }\end{array}$ & BAP (mg/l) & $\begin{array}{l}\text { No. of cotyledonary } \\
\text { collar per callus }\end{array}$ \\
\hline 0.5 & 0 & $45.3 \pm 0.49 \mathrm{~d}$ \\
& 0.4 & $68.6 \pm 0.80 \mathrm{a}$ \\
& 1 & $51.6 \pm 0.49 \mathrm{c}$ \\
1.5 & 0 & $32.0 \pm 0.93 \mathrm{f}$ \\
& 0.4 & $63.0 \pm 0.85 \mathrm{~b}$ \\
7.0 & 1 & $41.3 \pm 0.66 \mathrm{e}$ \\
& 0 & $14.6 \pm 0.66 \mathrm{~h}$ \\
& 0.4 & $21.3 \pm 0.98 \mathrm{~g}$ \\
12.0 & 1 & $15.3 \pm 0.66 \mathrm{~h}$ \\
& 0 & 0 \\
& 0.4 & $14.3 \pm 0.66 \mathrm{~h}$ \\
& 1 & $5.3 \pm 0.55 \mathrm{i}$ \\
\hline
\end{tabular}

$\overline{\text { Data represents mean value } \pm \text { SE of three replicates; each experi- }}$ ment was repeated twice. Mean values followed by same letters within a column are not significantly different according to Duncan's multiple range test (DMRT) at $5 \%$ level

\section{Germination of somatic embryos, plant regeneration and acclimatization}

Mature somatic embryos derived from purple calli turned green and continued their maturation when transferred to MS medium without growth hormone or supplemented with BAP $(0.4 \mathrm{mg} / \mathrm{l}$; Table 5; Fig. 3i-m). The first sign of maturation was the formation of the early cotyledonary collar from the globular embryos on the surface of the purple calli after 4 weeks of culture (Fig. 3h). Maturation with gradual opening of the cotyledonary collar was observed (Fig. 3i, j). Tiny leaves started to emerge from the opening of the collar (Fig. 3j, k) and germinated after transfer to fresh media supplemented with BAP $(0.4 \mathrm{mg} / \mathrm{l})$. Hook type of germination was observed from the collars (Fig. 31, m). Higher number of cotyledonary collars was observed on MS medium supplemented with $0.4 \mathrm{mg} / \mathrm{l}$ of BAP compared with $1 \mathrm{mg} / \mathrm{l}$ of BAP (Table 5). The calli derived from the lower concentrations of picloram $(0.5$ and $1.5 \mathrm{mg} / \mathrm{l}$ ) showed maximum cotyledonary collars compared with the calli derived from higher concentrations of picloram (7 and $12 \mathrm{mg} / \mathrm{l}$; Table 5). This may be due to the effect of higher concentrations of picloram, which produced compact globular structures and calli of this type did not turn purple upon being transferred to the medium containing activated charcoal. Opaque compact structures, which were observed on picloram $(0.5 \mathrm{mg} / \mathrm{l})$ germinated with low frequency on MS medium supplemented with $\operatorname{BAP}(0.4 \mathrm{mg} / \mathrm{l})$.

The present study revealed that BAP is effective in the germination of somatic embryos but only at a low concentration (Table 5). At a higher concentration, shoot induction frequency was significantly reduced. Poor germination of embryos is a major limitation associated with somatic embryogenesis in many plants (Odutayo et al. 2005). The maturation, germination, and conversion of somatic embryos into plantlets are post-somatic embryogenetic developmental stages critical for successful plant regeneration. Sequences of observations were made in the somatic embryo development of $D$. floribunda (Ammirato 1984; Twyford and Mantell 1996). Ammirato (1984) observed the formation of a cotyledonary collar surrounding the first leaf primordium in each somatic embryo in $D$. floribunda. Osifo (1988) observed fan-shaped cotyledonous structures in the initial stage of somatic embryo induction, similar to the zygotic embryo explants of $D$. rotundata, which developed into plantlets. In addition, Twyford and Mantell (1996) also observed the cotyledonary collar and hook type of germination in D. alata. In the present study, cotyledonary collars, and fan-shaped and hook types of germination were observed (Fig. 3f-m). The present results are in agreement with previous reports described for somatic embryogenesis in yam species. To the best of our knowledge, until now there has been no pictorial representation of somatic embryo induction, development, and germination in D. rotundata. This is the first report documenting globular, cup- or fan-shaped cotyledonary collars and hook type of germination in $D$. rotundata using pictures from the digital microscope (Fig. 3). Adventitious shoots were also germinated from callus clusters through organogenesis (Fig. 3n). After germination, the plants were separated and cultured in YBM for proper shoot elongation and rooting for 4 weeks (Fig. 3q). The germinated plants were successfully acclimatized in peat pellets, covered with polythene bags for 4 weeks, transferred to soil and manure in 1:1 ratio, and covered with polythene bags for 4 weeks. The plants were acclimatized slowly by making holes in the polythene bags and released to the environment with $90 \%$ survival rate (Fig. 3r, s). No apparent morphological variation was observed between the regenerated plantlets and the donor plants (Fig. 3t).

\section{Histological analysis}

Histological examination from the plant materials revealed the ontogeny of somatic embryogenesis and organogenesis in $D$. rotundata. The apical regions of the axillary bud with dividing meristematic cells were observed in the initial explants cultured for callus induction (Fig. 4a). In first 4 weeks of culture, emergence of direct somatic embryos was observed and proliferation of embryogenic and nonembryogenic calli was noticed in 8 weeks of culture (Fig. 4b, c). Direct embryos, which are of multicellular origin, emerged at the outer proliferating apical region of 
axillary bud explants cultured on MS medium containing picloram $(0.5 \mathrm{mg} / \mathrm{l})$ with casein hydrolysate and proline after 4 weeks of culture (Fig. 4b). The embryogenic cells have a prominent nucleus and a thin cell wall, confirming fast cell division with embryogenic proficiency. The protuberances that emerged in 4 weeks of culture progressed into calli containing embryogenic cells (as indicated by red arrows in Fig. 4c). Non-embryogenic cells were also observed in 8 weeks of culture (as indicated by white arrows in Fig. 4c). In the present study, induction and differentiation of somatic embryos were asynchronous on the surface of the calli and continuous successive division was observed in all directions of the embryogenic calli containing starch grains which gave rise to small globular structures clearly of multicellular origin, confirming induction of indirect somatic embryos (Fig. 4d, e). Viana and Mantell (1989) also demonstrated similar structures in D. composita and D. cayenensis. Their observations concluded that globular structures were induced in the peripheral layers as multicellular aggregates composed of densely cytoplasmic meristematic cells. Generally, clusters of somatic embryos are formed by meristematic cells with a dense cytoplasm, large nucleus, and many starch grains as observed in histological analysis of callus produced on MS medium containing picloram $(0.5 \mathrm{mg} / \mathrm{l})$ with casein hydrolysate and proline after 8 weeks of culture (Fig. 4d, e). The accumulation of starch grains in the somatic embryos provides an energy source for the development of embryos in oil palm (Kanchanapoom and Domyoas 1999). The histological sections in the present study also demonstrated formation of adventitious shoots from callus (Fig. 4f). The embryos were documented with shoot apical meristems (red arrow), root apical meristems (white arrow) connected with vascular tissues, (Fig. $4 \mathrm{~g}$, h) and further germinated into plantlets (Fig. 4i). Similar observations were made in somatic embryos of Colocasia esculentum during maturation and germination and concluded the shoot meristem and root meristem is connected by vascular tissues (Pradeep et al. 2009).

The histological studies demonstrated that that regeneration of D. rotundata via callus reported here is through both somatic embryogenesis and organogenesis leading to production of adventitious shoots.

\section{Conclusion}

In the present study, an efficient and reliable plant regeneration protocol was established for $D$. rotundata. The method developed using axillary bud as an explant is simpler and more reliable since the vines are easily propagated in vitro all year round, hence there is no limitation to starting explants. MS medium supplemented with
$0.5 \mathrm{mg} / \mathrm{l}$ picloram proved to be optimum for embryogenic calli induction. Addition of organic nitrogenous additives such as casein hydrolysate $(600 \mathrm{mg} / \mathrm{l})$ and proline $(1 \mathrm{~g} / \mathrm{l})$ improved the efficiency of production of embryogenic calli. Activated charcoal $(1 \%)$ played a significant role in inducing both adventitious shoot buds and somatic embryo induction and maturation. The mature embryos and adventitious shoot buds germinated on MS medium supplemented with $0.4 \mathrm{mg} / \mathrm{l} \mathrm{BAP}$. Histology studies confirmed that the regeneration of $D$. rotundata reported here is through both somatic embryogenesis and adventitious shoot regeneration. The calli produced on MS medium containing picloram $(0.5 \mathrm{mg} / \mathrm{l})$ supplemented with casein hydrolysate and proline were both embryogenic and non-embryogenic. The embryogenic calli showed development of somatic embryos and their germination into complete plantlet, however non-embryogenic calli developed multiple shoots. The regeneration system reported here needs further improvement with selection of embryogenic calli at early stages in order to avoid production of adventitious shoots.

Acknowledgments This research was supported by the Bill and Melinda Gates Foundation. The authors would like to thank the Biosciences Eastern and Central Africa (BecA) hub/International Livestock Research Institute, Kenya, for providing the laboratory facilities and Kenyatta University, Nairobi for providing facility for microtomy. The authors appreciate technical assistance from June Micheaka and Easter Syombua.

Author contributions L.T. conceived the idea and designed the experiments. M.R. performed the experiments and contributed to writing the manuscript. J.T. analyzed the data. All authors contributed to writing and editing the manuscript.

Open Access This article is distributed under the terms of the Creative Commons Attribution 4.0 International License (http://creative commons.org/licenses/by/4.0/), which permits unrestricted use, distribution, and reproduction in any medium, provided you give appropriate credit to the original author(s) and the source, provide a link to the Creative Commons license, and indicate if changes were made.

\section{References}

Adegbite AA, Saka JO, Agbaje GO, Owolade OF, Olaifa GO, Lawal A, Ojo ST (2006) Survey of plant parasitic nematodes associated with yams in Edo, Ekiti and Oyo States of Nigeria. Afr J Agric Res 1:125-130

Adeniyi OJ, Adetimirin VO, Ingelbrecht I, Asiedu R (2008) Shoot and plantlet regeneration from meristems of Dioscorea rotundata Poir and Dioscorea alata L. Afr J Biotechnol 7:1003-1008

Ammirato PV (1984) Yams. In: Ammirato PV, Evans DA, Sharp WR, Yamada Y (eds) Handbook of plant cell culture, Vol 3, Crop species. Macmillan, New York, pp 327-354

Amusa NA, Adegbite AA, Muhammed S, Baiyewu RA (2003) Yam diseases and its management in Nigeria. Afr $\mathrm{J}$ Biotechnol 2:497-502

Anike FN, Konan K, Olivier K, Dodo H (2012) Efficient shoot organogenesis in petioles of yam (Dioscorea spp). Plant Cell Tissue Org Cult 111:303-313. doi:10.1007/s11240-012-0195-9 
Asiedu R, Sartie A (2010) Crops that feed the world 1. Yams. Food Secur 2:305-315. doi:10.1007/s12571-010-0085-0

Belarmino MM, Gonzales JR (2008) Somatic embryogenesis and plant regeneration in purple food yam (Dioscorea alata L.). Ann Trop Res 30:22-33

Bhansali RR, Singh M (2000) Somatic embryogenesis in fruit and forest trees of arid zone. In: Jain SM, Gupta PK, Newton RJ (eds) Somatic embryogenesis in woody plants, vol 6. Kluwer, Dordrecht, pp 141-168. doi:10.1007/978-94-017-3030-3

Borges M, Ceiro W, Meneses S, Aguilera N, Vázquez J (2004) Regeneration and multiplication of Dioscorea alata germplasm maintained in vitro. Plant Cell Tissue Org Cult 76:87-90. doi:10. 1023/A: 1025804516226

FAOSTAT (C) FAO (2013) http://www.faostat.fao.org

Feher A, Pasternak T, Dudits D (2003) Transition of somatic plant cells to an embryogenic state. Plant Cell Tissue Org Cult 74:201-228. doi:10.1023/A:1024033216561

Feitosa T, Bastos JLP, Ponte LFA, Jucá TL, Campos FAP (2007) Somatic embryogenesis in cassava genotypes from the northeast of Brazil. Braz Arch Biol Technol 50:201-206

Filonova LH, Bozhkov PV, Von Arnold S (2000) Developmental pathway of somatic embryogenesis in Picea abies as revealed by time-lapse tracking. J Exp Bot 51:249-264

Gaj MD (2004) Factors influencing somatic embryogenesis induction and plant regeneration with particular reference to Arabidopsis thaliana (L.) Heynh. Plant Growth Regul 43:27-47

George EF, Hall MA, De Klerk GJ (2008) Plant propagation by tissue culture, vol 1, 3rd edn. Springer, Dordrecht. doi:10.1007/978-14020-5005-3

Gray DJ, Conger BV (1985) Influence of dicamba and casein hydrolysate on somatic embryo number and culture quality in cell suspensions of Dactylis glomerata (Gramineae). Plant Cell Tissue Org Cult 4:123-133. doi:10.1007/BF00042270

Ile IE, Crauford PQ, Battey NH, Asiedu R (2006) Phases of dormancy in yam tubers (Dioscorea rotundata). Ann Bot 97:497-504. doi:10.1093/aob/mc1002

Jimenez VM (2001) Regulation of in vitro somatic embryogenesis with emphasis on to the role of endogenous hormones. Rev Bras Fisiol Veg 13:196-223

Kanchanapoom K, Domyoas P (1999) The origin and development of embryoids in oil palm (Elaeis guineensis Jacq.) embryo culture. Sci Asia 25:193-200. doi:10.2306/scienceasia1513-1874.1999. 25.195

Khaleda L, Al-Forkan M (2006) Stimulatory effects of casein hydrolysates and proline in in vitro callus induction and plant regeneration from five deep water rice (Oryza sativa L.). Biotechnology 5:379-384. doi:10.3923/biotech.2006.379.384

Klu GYP, Asare EK, Blay ET, Ng SYC (2005) Effect of medium type and incubation duration on improved in vitro tuberization in three Dioscorea rotundata Poir cultivars. Plant Genet Resour Newslett 144:24-29

Krishnaraj S, Vasil IK (1995) Somatic embryogenesis in herbaceous monocots. In: Thorpe TA (ed) In vitro embryogenesis in plants. Kluwer, Dordrecht, pp 417-471. doi:10.1007/978-94-011-04852_11

Lincy KA, Remashree AB, Sasikumar B (2009) Indirect and direct somatic embryogenesis from aerial stem explants of ginger (Zingiber officinale Rosc.). Acta Bot Croat 68:93-103

López-Pérez AJ, Carreño J, Martínez-Cutillas A, Dabauza M (2005) High embryogenesis ability and plant regeneration of table grapevine cultivars (Vitis vinifera L.) induced by activated charcoal. Vitis 44:79-85

Malabadi RB, van Staden J (2006) Cold enhanced somatic embryogenesis in Pinus patula is mediated by calcium. S Afr J Bot 72:613-618. doi:10.1016/j.sajb.2006.04.001
Mariashibu TS, Subramanyam K, Arun M, Theboral J, Rajesh M, Rengan SK et al (2013) Assessment of somatic embryogenesis potency in Indian soybean [Glycine $\max (\mathrm{L})$ Merr.] cultivars. Indian J Exp Biol 51:849-859

Mignouna HD, Abang MM, Asiedu R (2008) Genomics of yams, a common source of food and medicine in the tropics. In: Moore P, Ming R (eds) Plant genetics and genomics: crops and models. Springer, Berlin, pp 549-570. doi:10.1007/978-0-387-71219-2 23

Moura-Costa PH, Viana AM, Mantell SH (1993) In vitro plantlet regeneration of Ocotea catharinensis, an endangered Brazilian hardwood forest tree. Plant Cell Tissue Org Cult 35:279-286. doi:10.1007/BF00037282

Nagasawa A, Finer JJ (1989) Plant regeneration from embryogenic suspension cultures of Chinese yam (Dioscorea opposita Thunb.). Plant Sci 60:263-271. doi:10.1016/0168-9452(89)90176-3

Nirwan RS, Kothari SL (2003) High copper levels improve callus induction and plant regeneration in Sorghum bicolor (L.) Moench. In Vitro Cell Dev Biol Plant 39(2):161-164. doi:10. 1079/IVP2002385

Nyaboga E, Njiru J, Nguu E, Gruissem W, Vanderschuren H, Tripathi L (2013) Unlocking the potential of tropical root crop biotechnology in east Africa by establishing a genetic transformation platform for local farmer-preferred cassava cultivars. Front Plant Sci 4:526. doi:10.3389/fpls.2013.00526

Nyaboga E, Tripathi JN, Manoharan R, Tripathi L (2014) Agrobacterium-mediated genetic transformation of yam (Dioscorea rotundata): an important tool for functional study of genes and crop improvement. Front Plant Sci 5:463. doi:10.3389/fpls. 2014.00463

Odutayo O, Akinrimisi FB, Ogunbosoye I, Oso RT (2005) Multiple shoot induction from embryo derived callus cultures of cowpea (Vigna unguiculata L.) Walp. Afr J Biotechnol 4:1214-1216

Okunlola A, Odeku OA (2011) Evaluation of starches obtained from four Dioscorea species as binding agent in chloroquine phosphate tablet formulations. Saudi Pharm J 19:95-105. doi:10. 1016/j.jsps.2011.01.002

Osifo FO (1988) Somatic embryogenesis in Dioscorea. J Plant Physiol 133:378-380. doi:10.1016/S0176-1617(88)80221-9

Ovono PO, Kevers C, Dommes J (2007) Axillary proliferation and tuberization of Dioscorea cayenensis-Dioscorea rotundata complex. Plant Cell Tissue Org Cult 91:107-114. doi:10.1007/ s11240-007-9238-z

Pasternak T, Prinsen E, Ayaydin F, Miskolczi P, Potters G, Asard H, Van Onckelen H, Dudits D, Fehér A (2002) The role of auxin, $\mathrm{pH}$ and stress in the activation of embryogenic cell division in leaf protoplast-derived cells of alfalfa (Medicago sativa L.). Plant Physiol 129:1807-1819. doi:10.1104/pp.000810

Poornima G, Ravishankar RV (2007) In vitro propagation of wild yams, Dioscorea oppositifolia L. and Dioscorea pentaphylla L. Afr J Biotechnol 20:2348-2352

Pradeep CD, Harding RM, Taylor M, Tyagi AP, Becker DK (2009) Somatic embryogenesis, organogenesis and plant regeneration in taro (Colocasia esculenta var. esculenta). Plant Cell Tissue Org Cult 99:61-71. doi:10.1007/s11240-009-9576-0

Prakash MG, Gurumurthi K (2010) Effects of type of explant and age, plant growth regulators and medium strength on somatic embryogenesis and plant regeneration in Eucalyptus camaldulensis. Plant Cell Tissue Org Cult 100:13-20. doi:10.1007/ s11240-009-9611-1

Ramakrishnan M, Ceasar SA, Duraipandiyan V, Melvin AD, Ignacimuthu S (2013) Efficacious somatic embryogenesis and fertile plant recovery from shoot apex explants of onion (Allium cepa L.). In Vitro Cell Dev Biol Plant 49:285-293. doi:10.1007/ s11627-013-9510-3 
Sarker KK, Kabir AH, Sarmin AH, Nasrin Z, Alam MF (2007) Improved somatic embryogenesis using L-Asparagine in wheat (Triticum aestivum L.). Sjemenarstvo 24:3-4

Suarez Padron IE, Torres Arizal LA, Litz R (2011) Somatic embryogenesis in yam (Dioscorea rotundata). Rev Fac Nal Agr Medellín 64(2):6037-6042

Takamori LM, Neto NBM, Vieira LGE, Ribas AF (2015) Optimization of somatic embryogenesis and in vitro plant regeneration of Urochloa species using picloram. In Vitro Cell Dev Biol Plant 51:554-563. doi:10.1007/s11627-015-9701-1

Thomas TD (2008) The role of activated charcoal in plant tissue culture. Biotechnol Adv 26:618-631. doi:10.1016/j.biotechadv. 2008.08.003

Triqui ZEA, Guedira A, Chlyah A, Chlyah H, Souvannavong V, Haicour R, Sihachakr D (2008) Effect of genotype, gelling agent and auxin on the induction of somatic embryogenesis in sweet potato (Ipomoea batatas Lam). Comptes Rendus Biol 331:198-205. doi:10.1016/j.crvi.2007.11.009
Twyford CT, Mantell SH (1996) Production of somatic embryos and plantlets from root cells of Greater Yam. Plant Cell Tissue Org Cult 46:17-26. doi:10.1007/BF00039692

Viana AM, Mantell SH (1989) Callus induction and plant regeneration from excised zygotic embryos of the seed-propagated yams Dioscorea composita Hemsl. and D. cayenensis Lam. Plant Cell Tissue Org Cult 16:113-122. doi:10.1007/BF00036519

Weatherhead MA, Burdon J, Henshaw GG (1978) Some effects of activated charcoal as an additive to plant tissue culture media. Z Pflanzenphysiol 89:141-147. doi:10.1016/S0044-328X(78) 80054-3

Zimmerman JL (1993) Somatic embryogenesis: a model for early development in higher plants. Plant Cell 5:1411-1423. doi:10. 1105/tpc.5.10.1411

Zuluaga MF, Baena Y, Mora CE, D’León LFP (2007) Physicochemical characterization and application of yam (Dioscorea cayenensis-rotundata) starch as a pharmaceutical excipient. Starch 59:307-317. doi:10.1002/star.200600516 